\title{
Polymer flooding - Does Microscopic Displacement Efficiency Matter?
}

\author{
Guangyuan Sun ${ }^{1}$; Bernd Crouse ${ }^{1 *}$; David M. Freed ${ }^{1}$; Rui Xu ${ }^{1}$; Juan Bautista ${ }^{1}$; Raoyang Zhang ${ }^{2}$; Hiroshi Otomo ${ }^{2}$; \\ Yong $\mathrm{Li}^{2}$; Hudong Chen²; Hongli Fan²; Marco Dressler ${ }^{2}$ \\ ${ }^{1}$ Dassault System, 150 North Hill Drive, Brisbane, California, USA 94005 \\ ${ }^{2}$ Dassault System, 55 Network Dr, Burlington, MA USA 01803 \\ E-mail: bernd.crouse@3ds.com
}

\begin{abstract}
Polymer flooding is an enhanced oil recovery (EOR) technique that aims to enhance the stability of the flood front in order to increase sweep efficiency and thereby increase hydrocarbon recovery. Polymer flooding studies often focus on large-scale sweep efficiency and neglect the impact of the pore-scale displacement efficiency of the multi-phase flow. This work explores the pore-scale behavior of water vs polymer flooding, and examines the impact of rock surface wettability on the microscopic displacement efficiency using digital rock physics. In this study, a micro-CT image of a sandstone rock sample was numerically simulated for both water and polymer flooding under oil-wet and water-wet conditions. All simulations were performed at a capillary number of $1 \mathrm{E}-5$, corresponding to a capillary dominated flow regime. Results of the four two-phase flow imbibition simulations are analyzed with respect to displacement character, water phase break-through, viscous/capillary fingering, and trapped oil. In the water-wet scenario, differences between water flood and polymer flood are small, with the flood front giving a piston-like displacement and breakthrough occurring at about 0.4 pore volume (PV) for both types of injected fluid. On the other hand, for the oil-wet scenario, water flood and polymer flood show significant differences. In the water flood, fingering occurs and much of the oil is bypassed early on, whereas the polymer flood displaces more oil and thereby provides better microscopic sweep efficiency throughout the flood and especially around breakthrough. Overall the results for this rock sample indicate that water flood and polymer flood provide similar recovery for a water-wet condition, while the reduced mobility ratio of polymer flood gives significantly improved recovery for an oil-wet condition by avoiding the onset of microscopic (pore-scale) fingering that occurs in the water flood. This study suggests that depending on the rock-fluid conditions, the use of polymer can impact microscopic sweep efficiency, in addition to the well-known effect on macroscopic sweep behavior.
\end{abstract}

Key words: Polymer flood, water flood, Enhanced Oil Recovery (EOR), wettability, microscopic displacement efficiency, digital rock physics (DRP)

\section{Estudio del Desplazamiento Microscópico Durante la Inyección de Polímero}

La inyección de polímeros es una técnica de recobro mejorado de petróleo (EOR) que tiene como objetivo mejorar la estabilidad del frente de inyección para aumentar la eficiencia del desplazamiento de hidrocarburos y, por lo tanto, incrementar el factor de recobro. Lo estudios de inyección de polímeros a menudo se centran en la eficiencia del desplazamiento a gran escala e ignoran el impacto de los mecanismos de desplazamiento a escala microscópica, y rara vez evalúan la variabilidad de parámetros de flujo multifásico en el medio poroso. Este trabajo explora el comportamiento del agua contra la inyección de polímeros en el medio poroso, y examina el impacto de la humectabilidad de la superficie de la roca en la eficiencia de desplazamiento microscópico, utilizando tomografía computarizada de rayos X en muestras de roca. En este estudio, se simuló numéricamente una imagen de microtomografía computarizada de una muestra de roca arenisca, para un proceso de inyección de agua y polímeros en condiciones de mojabilidad al aceite y al agua. Todas las simulaciones se realizaron a un número capilar de 1E-5, correspondiente a un régimen de flujo dominado por fuerzas capilares y que es típico del flujo en yacimientos de hidrocarburos. Los resultados de las cuatro simulaciones de imbibición de flujo de dos fases se analizan con respecto al carácter desplazante, el avance de la fase acuosa, la digitación viscosa y capilar, y el aceite atrapado. En el escenario de mojabilidad al agua, las diferencias entre la inyección de agua y la inyección de polímeros son pequeñas, dado que el frente de inyección produce un

Cita: Sun, G., Crouse, B., Fredd, D.M., Xu, R., Bautista, J., Zhang, R., Otomo, H., Li, Y., Chen, H., Fan, H y Dressler, M. (2018). Polymer flooding - Does Microscopic Displacement Efficiency Matter?. Revista Fuentes: El reventón energético, 16(2), 83-90. 
desplazamiento en forma de pistón y un avance que se produce a aproximadamente 0,4 volúmenes porosos para ambos tipos de fluido inyectado. Por otro lado, para el escenario de mojabilidad al petróleo, la inyección de agua y la inyección de polímeros muestran diferencias significativas. En la inyección de agua, se produce digitación y gran parte del petróleo se pasa por alto al principio; mientras que la inyección de polímeros desplaza más aceite y, por lo tanto, proporciona una mejor eficiencia de desplazamiento microscópico durante la inyección, especialmente alrededor de la ruptura. En general, los resultados para esta muestra de roca indican que la inyección de agua y la inyección de polímeros proporcionan un efecto de recobro similar para una condición de mojabilidad al agua, mientras que la relación de movilidad reducida de la inyección de polímeros proporciona un efecto de recobro significativamente mejorado para una condición de mojabilidad al aceite, al evitar la aparición de digitación microscópica (a escala de poro) que se produce en la inyección de agua. Este estudio sugiere que, dependiendo de las condiciones roca-fluido, el uso del polímero puede impactar la eficiencia de desplazamiento microscópico, además del efecto conocido sobre el comportamiento del desplazamiento macroscópico.

Palabras Claves: Inyección de polímero, Recobro mejorado, Mojabilidad, Eficiencia microscópica de desplazamiento, Petrofísica Digital

\section{Introduction}

For most oil reservoirs, a large amount of oil is left behind in the formation trapped within the rock, even after extensive water flooding. A contributing factor to poor sweep efficiency of a water flood can be fingering of the injected fluid into preferred paths, resulting in a lot of bypassed oil. As early as the 1960s, polymer flooding has been suggested as an enhanced oil recovery (EOR) method that could improve the oil displacement process by increasing the viscosity of the displacing fluid (Pinto et al, 2018).

In polymer flooding, low concentrations of water soluble and high molecular weight polymer are added to the injected water to reduce the mobility of the displacing phase and thereby decrease the tendency for viscous fingering. Mobility $(\lambda)$ is defined as the ratio of the relative permeability $\left(k_{r}\right)$ of the fluid (i.e. water or oil) to the viscosity $(\mu)$ of the same fluid (Meneses et al, 2017). The mobility ratio $(M)$ compares the mobility of displacing and displaced fluid phases in porous media, and a high mobility ratio can lead to the fingering phenomena resulting in an undesirable loss of sweep efficiency (Velandia, 2013).

The overall sweep efficiency is the product of the macroscopic displacement efficiency and the microscopic displacement efficiency (Al-Mjeni, et al. 2011). The macroscopic displacement efficiency occurs at the scale of inter-well distance, and is reduced when oil is bypassed because of lateral or vertical formation heterogeneity, well-pattern inefficiencies or low injected fluid viscosity (Muggeridge et al. 2014). A lot of field scale advances have been made to improve macroscopic displacement efficiency, e.g. adjusting the well pattern to account for reservoir heterogeneity, applying seismic methods to follow a flood front through a reservoir, balancing flow in different zones by decreasing thiefzone permeabilities, and using high viscosity displacing fluids to improve unfavorable mobility ratio (Al-Mjeni, et al. 2011).

The microscopic displacement efficiency, which concerns the flow behavior at the pore scale, is also very important to the overall oil production. Oil can remain trapped within swept pore space because the viscous forces did not overcome the capillary forces, or because of bypassed pore space due to microscopic fingering. At the pore level, wettability is a key physical property influencing displacement and trapping mechanisms and therefore the oil recovered by flooding. Recent laboratory studies of polymer flooding describe some mechanisms of oil trapping and displacement (Du \& Guan, 2004) (Yuming et al., 2013); however, the role of wettability in the microscopic displacement performance of a polymer flood is not well studied.

The objective of this study is to use a digital rock physics approach to investigate the pore-scale behavior of polymer flood compared to water flood for different wetting conditions. A micro-CT image of a sandstone rock sample was numerically simulated for both water and polymer flooding under oil-wet and waterwet conditions. Results of these four simulations are analyzed to compare oil productivity, injected fluid phase break-through, viscous/capillary fingering, and trapped/residual oil.

\section{Methods and Procedure}

Digital rock physics combines modern microscopic imaging with numerical simulations to predict important rock properties and better understand the physical phenomena occurring at the microscale. 


\section{Micro-CT imaging}

A Berea sandstone sample was selected for this work. Micro-CT scans were carried out on a cylindrical core sample of $5 \mathrm{~mm}$ inch diameter and $10 \mathrm{~mm}$ inch length to acquire $3 \mathrm{D}$ images of the pore structure with resolution of $2,02 \mu \mathrm{m}$ per voxel. Since the attenuation of X-rays within the sample are related to the material density, the micro-CT scans provide grey-scale images with color values related to the sample material (Figure 1 left). The resulting 3D image was denoised using typical image processing techniques including contrast enhancement and low-pass filtering (Figure 1 middle). Threshold segmentation was applied resulting in a binary image (Figure 1 right) suitable to be used as input to the numerical simulations. The resolved porosity is $15,7 \%$ and an absolute permeability of $235 \mathrm{mD}$ was obtained from single-phase flow simulation. An imaging domain of 500x500x500 voxels is chosen for the multi-phase flow simulations.
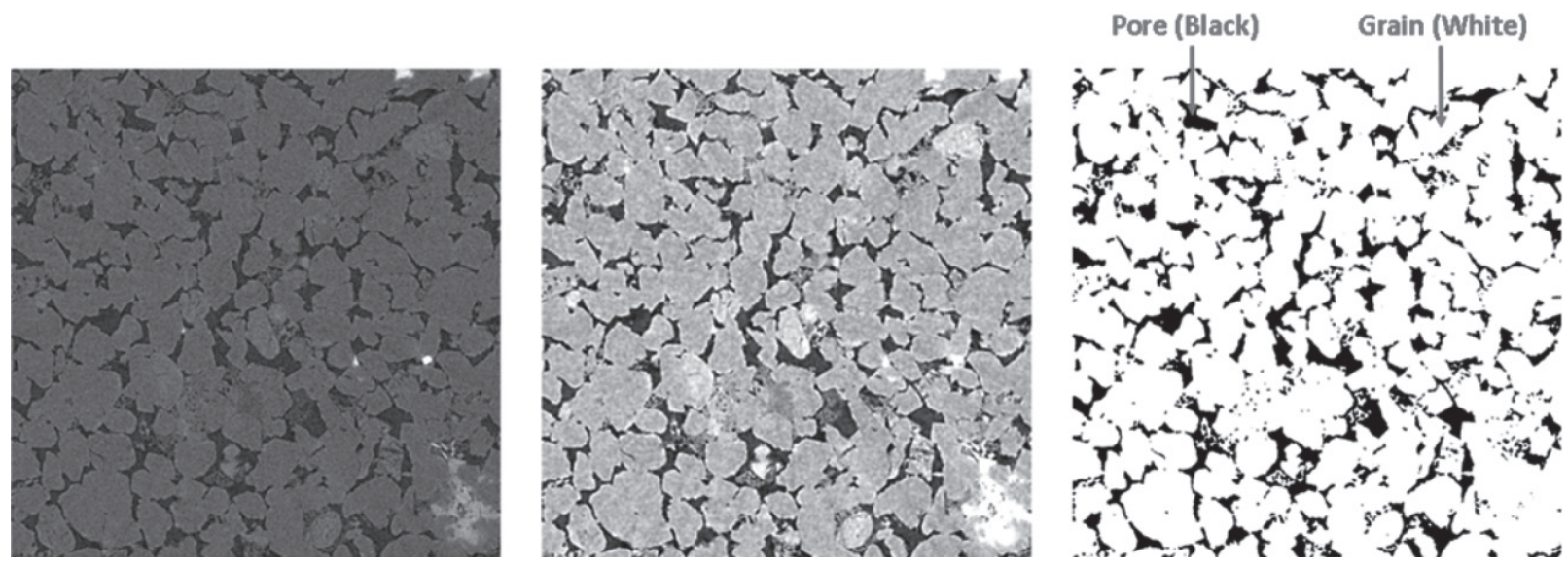

Figure 1. Berea sandstone core sample (left) greyscale image; (middle) denoised image; (right) binary image.

\section{Physical properties of system}

To prepare for the core flooding simulations, a primary drainage computation is performed to establish the initial fluid distribution in pore-space, representing the accumulation of hydrocarbons in the initially water filled reservoir rocks. The initial water saturations for water-wet and oil-wet are selected to be $20 \%$ and $5 \%$ respectively (Figure $2 \mathrm{a}$ and $2 \mathrm{c}$ ). It is assumed that during the drainage process, the smallest pores remain waterfilled, while the oil invades the remainder of the pore space. The pore surface can only become more oil-wet due to contact with oil and the rock will achieve a "mixed wettability" state. More detail on these widely accepted mechanisms of oil aging or wettability alteration can be found in e.g. Buckley, Liu \& Monsterleet (1998). In the present numerical procedure, the surfaces contacted by oil are assigned a $30^{\circ}$ and $175^{\circ}$ contact angle for the water-wet and oil-wet scenarios, respectively. Surfaces still in contact with water after primary drainage are assigned a contact angle $10^{\circ}$. The overall contact angle distributions are shown in Figures $2 b$ and $2 d$. For each wetting condition, the resulting fluid distributions at the pore level are at equilibrium, capillary-controlled conditions, providing a suitable initial condition for the flooding simulations.
After initial conditions are established by primary drainage in pore space, core flood (or imbibition process) is ready to perform. It is expected that as the flood progresses, oil becomes trapped within pore space as water finds flow paths around it. Once the water phase breaks the connection between the remaining oil blobs and the oil being swept out, the remaining oil blobs become much more difficult for the viscous forces to displace. A measure of the relative interaction between these forces is the capillary number, set to $1 \mathrm{E}-5$ in the present work to represent the typical reservoir system dominated by capillary effects. A study of capillary number on displacement behavior is described in $\mathrm{Xu}$ et al. (2018).

Mobility ratio $(M)$ is an important and useful parameter to quantify the mobility contrast between the displacing fluid (i.e. water) and the displaced phase (i.e. oil). The mobility ratio is given by the following expression.

$$
M=\lambda_{w} / \lambda_{o}=\frac{k_{r w} / \mu_{w}}{k_{r o} / \mu_{o}}
$$

Favorable mobility ratio $(M \leq 1)$ improves the displacement efficiency. The oil viscosity for polymer flooding is less than $200 \mathrm{cp}$ as traditional EOR screening 
criteria. Even so, there is increasing interest in applying polymer flooding in heavy-oil reservoirs with the oil viscosity even up to $10.000 \mathrm{cp}$. But the rheological properties of heavy oils and the characteristics of their reservoirs make its production a challenge for the

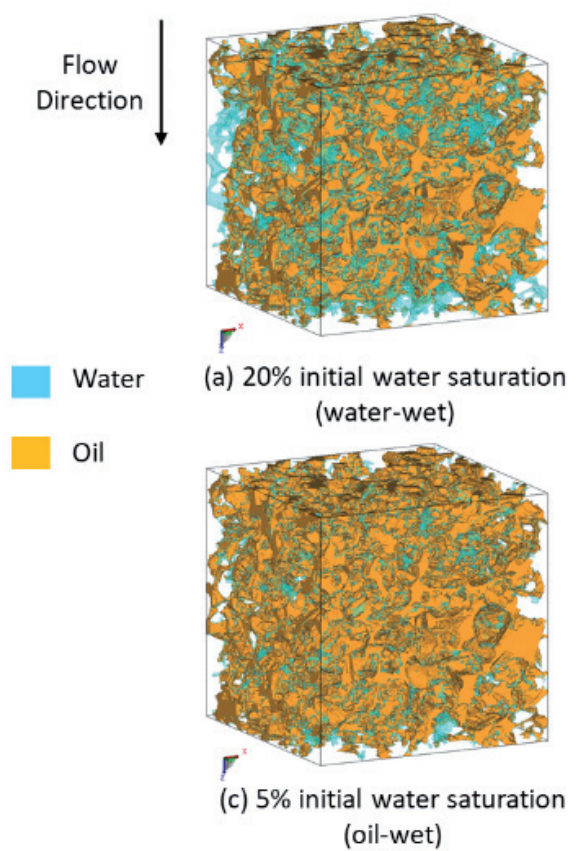

industry. In this study, oil/water viscosity ratios of 1 for polymer flood and 10 for water flood are used to investigate the effect of wettability on microscopic displacement behaviors.

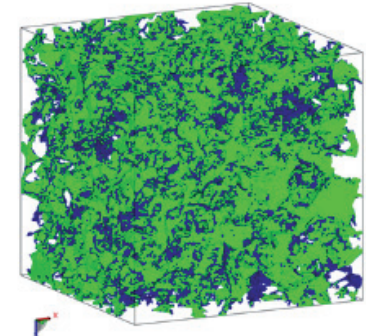

(b) Surface wettability (water-wet)

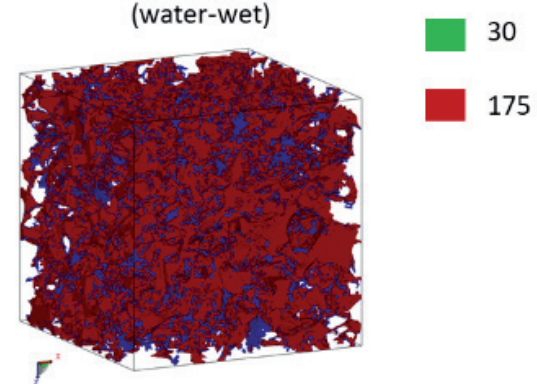

(d) Surface wettability (oil-wet)

Figure 2. Initial fluid distributions and surface wettability in water- and oil-wet tests.

\section{Numerical Simulation}

All flow simulations were performed using DigitalROCK ${ }^{\mathrm{TM}}$, which uses a numerical solver based on the Shan-Chen multi-phase lattice Boltzmann model (Shan \& Chen, 1993). This solver has been validated on a variety of fundamental benchmarks and real reservoir rock test cases (Crouse et al. 2016) (Jerauld et al. 2017) (Otomo et al. 2015) (Otomo et al. 2016) (Shan \& Chen, 1993) (Chen, Teixeira \& Molvig, 1998) (Shan, Yuan \& Chen, 2006) (Zhang, Shan \& Chen, 2006) (Chen, Zhang \&Gopalakrishnan, 2017). It also includes the ability to deal with high viscosity ratio of the immiscible fluid phases (Otomo et al. 2018).

The numerical solver effectively reproduces a typical coreflood test, but with all details of local fluid properties known throughout the procedure. During a flood, a series of measurement data (oil and water saturation, flow rates, differential pressure across the core) are recorded and later used to construct productivity curves, relative permeabilities, saturation profiles, visualizations, and other reported results. All simulations were performed at a capillary number of $1 \mathrm{E}-5$, corresponding to a capillary dominated flow regime, with the injected fluid entering at the top and both fluids flowing out of the bottom of the test section.

\section{Results}

Based on the simulation results, comparisons were made between polymer and water floods under waterwet and oil-wet conditions. The results presented include cumulative oil recovery vs injection volume, relative permeabilities, and fluid distribution profiles in the flow direction.

Figure 3 (left) presents the cumulative oil recovery obtained from water flood and polymer flood for both water-wet and oil-wet conditions. In the water-wet condition, cumulative oil recovery at end of production by polymer flood is $0,40 \mathrm{PV}$ and just slightly higher than 0,38 PV obtained by water flood. On the other hand, for oil-wet condition, after breakthrough the oil recovery by polymer flood is 0,08 to $0,12 \mathrm{PV}$ larger than by water flood, depending on the amount of injected fluid, and both types of flood yield larger cumulative oil recovery than both the water-wet floods. The polymer flood in the oil-wet case continues to have strongly increasing oil production longer than the other floods, indicating 
better microscopic displacement efficiency. Figure 3 (right) shows a similar trend to the oil-wet simulations for experimental core flood data using samples from a field in western Canada (Wassmuth, Green, Hodgins $\&$ Turta, 2007). Note that the oil/water viscosity ratio in polymer flood is 40 times smaller than in the water flood for this experiment, resulting in a larger difference than seen in the simulations which have a factor of 10 difference in viscosity ratio. It's also observed that for an oil-wet condition, both types of flood have a long production tail, because oil in contact oil-wet surfaces remains continuously connected at lower oil saturations than in a water-wet system, and therefore continues to be produced even after many injected pore volumes.

Figure 4 shows the oil and water relative permeability curves for polymer flood and water flood in waterwet and oil-wet scenarios. As seen in the production curves, the residual oil saturation is lower for polymer flooding than water flooding, and by a larger amount under oil-wet condition. Also the relative permeability of the water phase at the residual oil end point is larger for polymer flood than water flood for both wetting conditions.
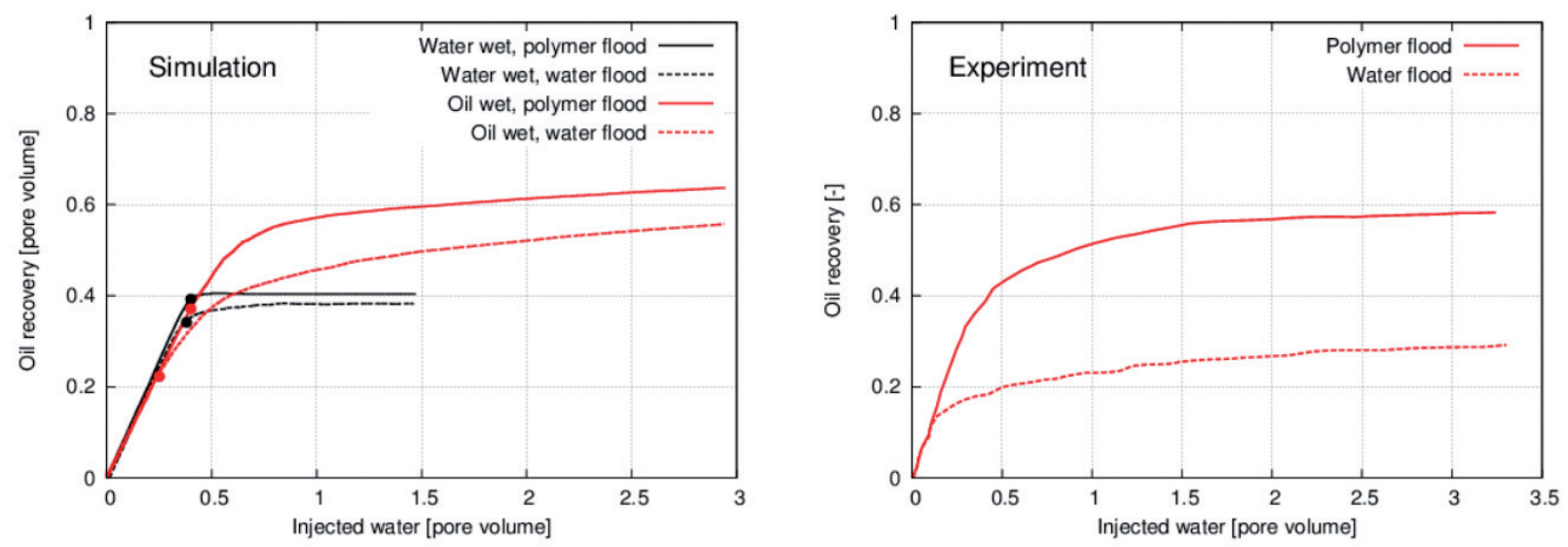

Figure 3. Cumulative oil recovery in waterflood and polymer flood: (left) Simulation, solid dots represent water breakthrough (right) coreflood experiment on sample from western Canada (Wassmuth 2007). The polymer/water viscosity ratio was higher in experiment (40) compared to simulation (10) causing the larger difference in oil recovery.
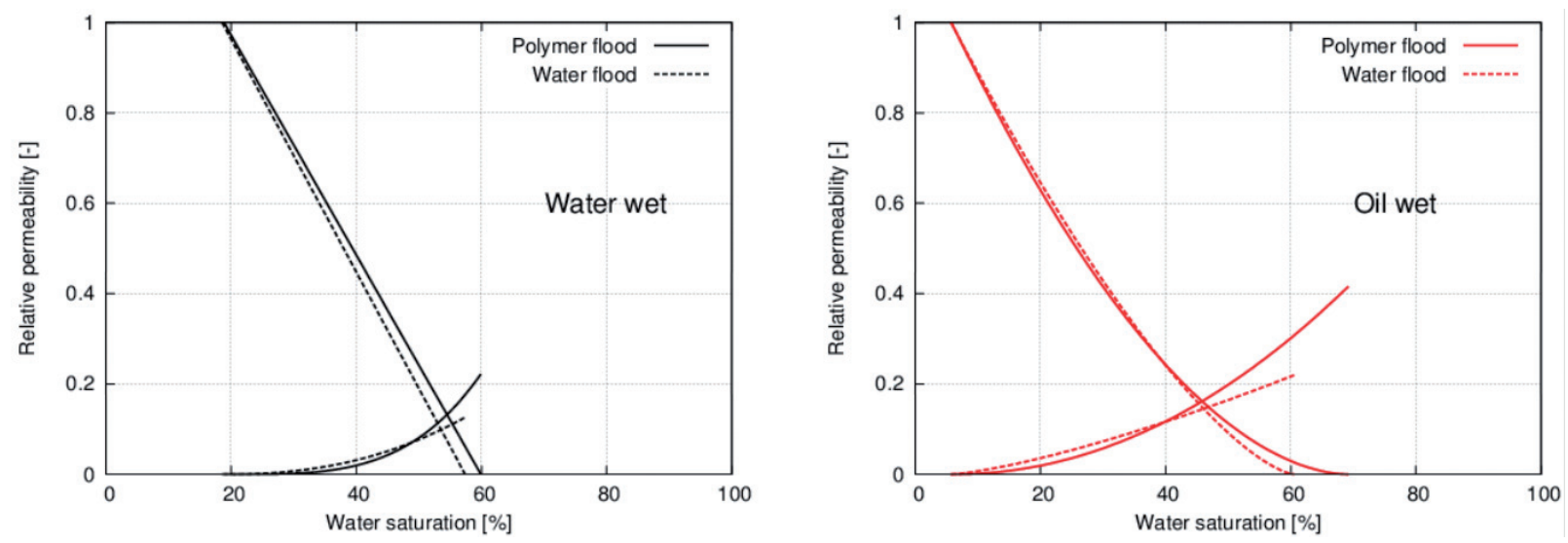

Figure 4. Relative permeability in polymer flood and water flood: (left) water-wet (right) oil-wet.

To better understand the role of wettability, injected water saturation profiles in the flow direction for polymer flood and water flood are shown together with fluid distribution visualizations in Figure 5-8. Figure 5 shows these results for the water-wet condition at the time of breakthrough, and Figure 6 shows waterwet results at the residual oil end point. It is seen that injected water in both floods reaches the outlet at the same time, as polymer flood does not help minimize viscous fingering and leaves a similar amount of trapped oil behind. In contrast, Figures 7 and 8 show that for the oil-wet condition, the polymer flood provides a more piston-like displacement behavior leading to better displacement efficiency and higher oil recovery. 
Figure 9 compares the saturation distribution of polymer flood and water flood in oil-wet tests at $60 \%$ water saturation. To reach the same $60 \%$ water saturation, 0,76 $\mathrm{PV}$ and 2,80 PV of water are injected in polymer flood and water flood, respectively, indicating the greater efficiency of the polymer flood for oil-wet condition.
It is interesting that despite the difference in injected fluid volumes, the fluid distributions match closely, indicating that the pore scale displacement and trapping mechanisms are dominated by capillary effects and that oil is removed from the pore space in the same order whether the flood front is stable or has fingering.

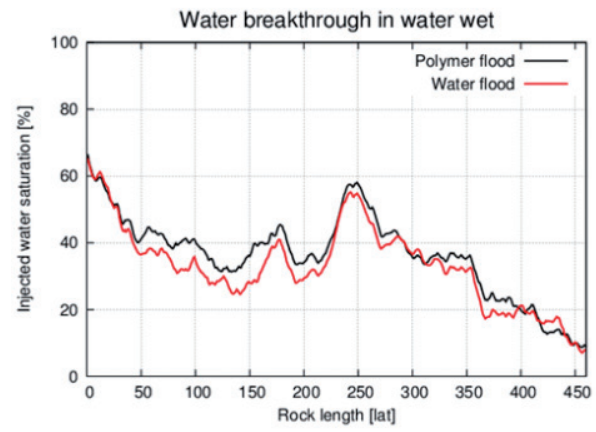

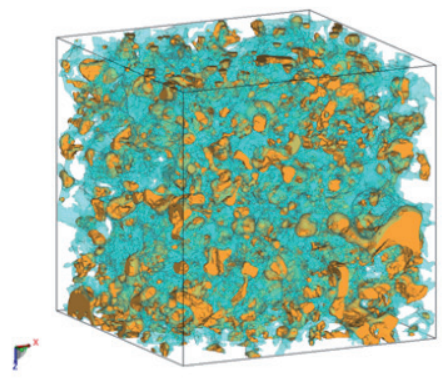

Polymer flood

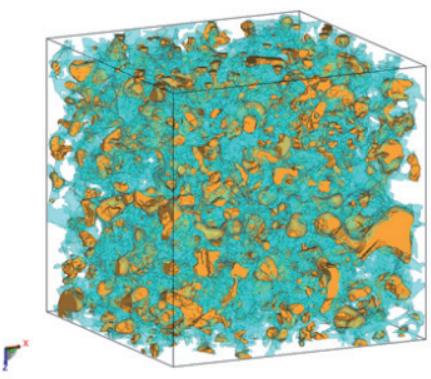

Water flood

Figure 5. Fluid distributions at breakthrough for water-wet condition: (left) injected water saturation profiles in flow direction; (middle) fluid distribution in polymer flood; (right) fluid distribution in water flood [water (light blue), oil (yellow)].

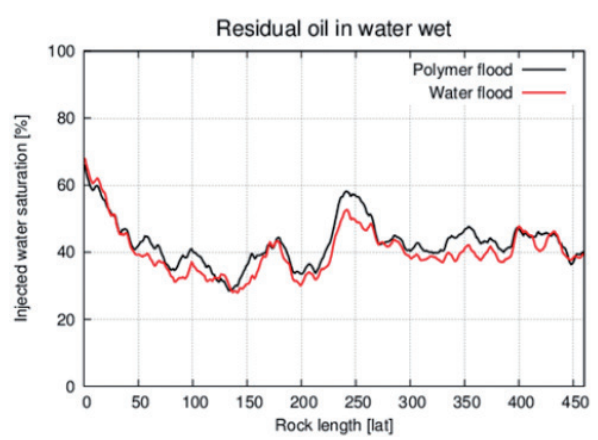

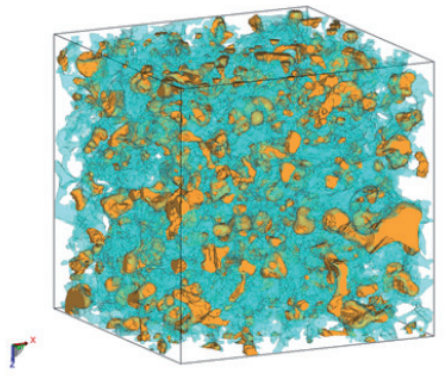

Polymer flood

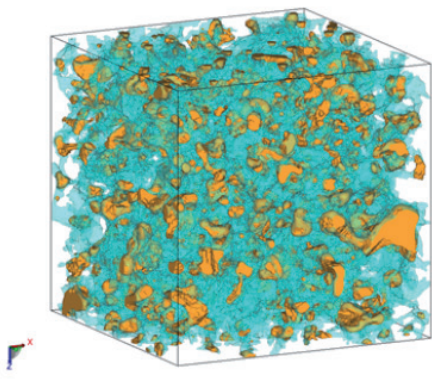

Water flood

Figure 6. Fluid distributions at residual oil in water-wet condition: (left) injected water saturation profiles in flow direction; (middle) fluid distribution in polymer flood; (right) fluid distribution in water flood [water (light blue), oil (yellow)].

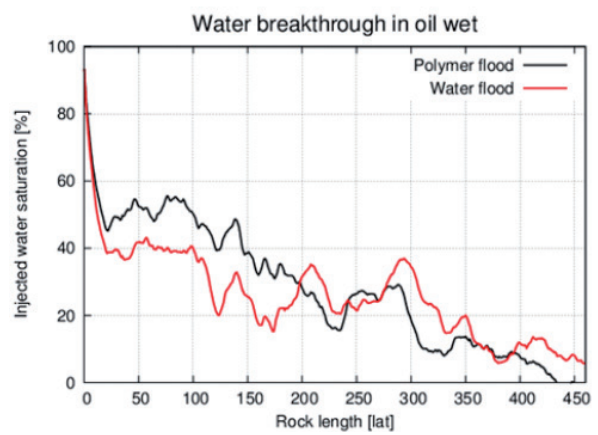

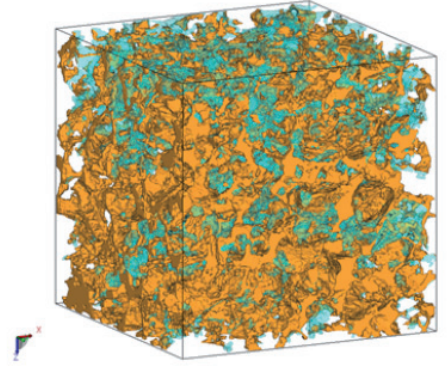

Polymer flood

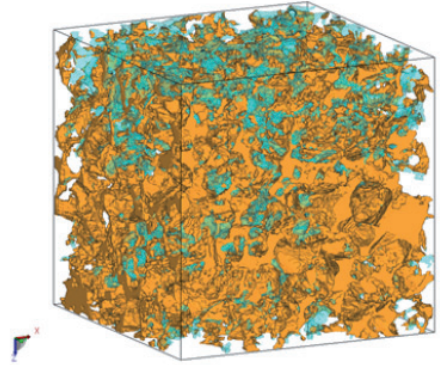

Water flood

Figure 7. Fluid distributions at breakthrough in oil-wet condition: (left) injected water saturation profiles in flow direction; (middle) fluid distribution in polymer flood at $0.4 \mathrm{PV}$; (right) fluid distribution in water flood at $0.25 \mathrm{PV}$ [water (light blue), oil (yellow)]. 

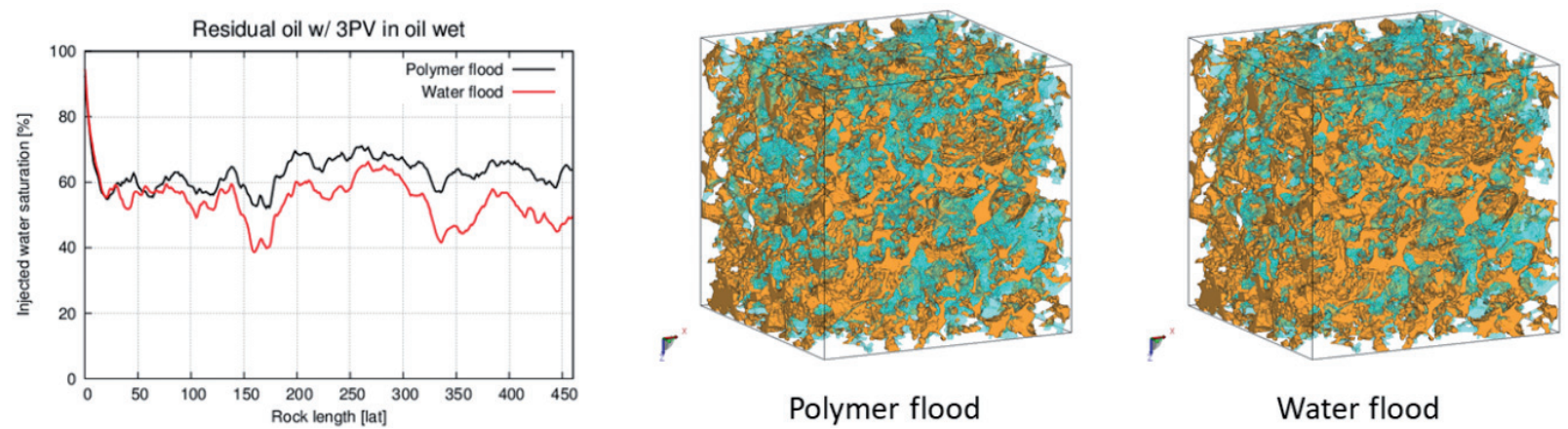

Figure 8. Fluid distributions at residual oil in oil-wet condition: (left) injected water saturation profiles in flow direction; (middle) fluid distribution in polymer flood at 3.0 PV; (right) fluid distribution in water flood (light blue) at $3.0 \mathrm{PV}$ [water (light blue), oil (yellow)].
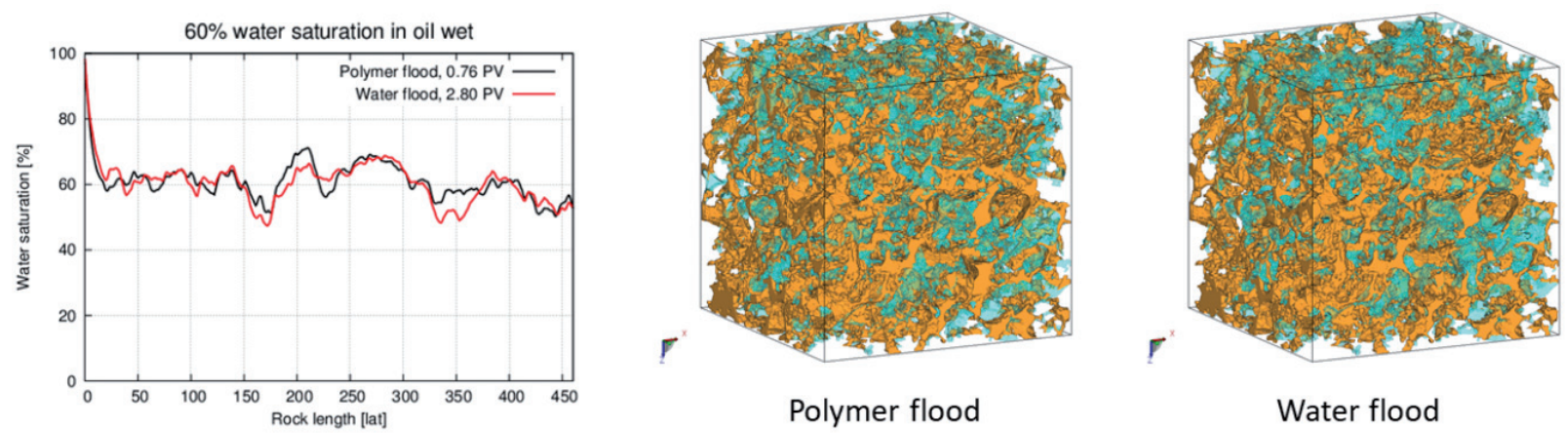

Figure 9. Fluid distributions at $60 \%$ water saturation in oil-wet condition: (left) water saturation profiles in flow direction; (middle) fluid distribution in polymer flood at $0.76 \mathrm{PV}$; (right) fluid distribution in water flood water at $2.80 \mathrm{PV}$ (light blue)

[water (light blue), oil (yellow)].

\section{Conclusions}

The pore-scale behavior and microscopic displacement efficiency of water vs polymer flooding for different wetting conditions was studied using digital rock physics applied to a sandstone rock sample. The displacement character, water phase break-through, viscous/capillary fingering, and trapped oil results were compared. In the water-wet scenario, differences between water flood and polymer flood were small, with the flood front giving a piston-like displacement and breakthrough occurring at about 0,4 pore volume (PV) for both types of injected fluid. On the other hand, for the oil-wet scenario, water flood and polymer flood gave significant differences. In the water flood, fingering occurs and much of the oil is bypassed early on, whereas the polymer flood displaces more oil and thereby provides better microscopic sweep efficiency throughout the flood and especially near breakthrough. These results indicate that water flood and polymer flood provide similar oil recovery for a water-wet condition, while the reduced mobility ratio of polymer flood gives significantly improved recovery for an oil-wet condition by avoiding the onset of microscopic (pore-scale) fingering that occurs in the water flood. This study suggests that depending on the rock-fluid conditions, the use of polymer can impact microscopic sweep efficiency, in addition to the wellknown effect on macroscopic sweep behavior.

\section{References}

1. Al-Mjeni, R.; Arora, S.; Cherukupalli, P.; Van Wunnik, J.; Edwards, J.; Felber, B.J.; Jackson, C. (2011) Has the time come for EOR? Oilfield Rev. 22, 16-37.

2. Buckley, J. S., Liu, Y., \& Monsterleet, S. (1998). Mechanisms of wetting alteration by crude oils. SPE journal, 3(01), 54-61.

3. Chen, H., Teixeira, C., \& Molvig, K. (1998). Realization of fluid boundary conditions via discrete Boltzmann dynamics. International Journal of Modern Physics C, 9(08), 1281-1292.

4. Chen, H., Zhang, R., \& Gopalakrishnan, P. (2017). U.S. Patent Application No. 15/402,732. 
5. Crouse, B., Freed, D. M., Koliha, N., Balasubramanian, G., Satti, R., Bale, D., \& Zuklic, S. (2016). A Lattice-Boltzmann Based Method Applied to Digital Rock Characterization of Perforation Tunnel Damage. In Paper SCA2016-058 presented at the International Symposium of the Society of Core Analysts held in Snow Mass, Colorado, USA.

6. Du, Y., \& Guan, L. (2004). Field-scale polymer flooding: lessons learnt and experiences gained during past 40 years. In SPE International Petroleum Conference in Mexico. Society of Petroleum Engineers.

7. Jerauld, G. R., Fredrich, J., Lane, N., Sheng, Q., Crouse, B., Freed, D. M., ... \& Xu, R. (2017). Validation of a Workflow for Digitally Measuring Relative Permeability. In SPE Abu Dhabi International Petroleum Exhibition \& Conference. Society of Petroleum Engineers.

8. Meneses, A. F. O., Moreno, L. F. C., \& Plata, J. A. R. (2017). Metodología experimental para la estimación de permeabilidades relativas en dos y tres fases por medio de ajuste histórico. Revista Fuentes, 15(1), 75-85.

9. Muggeridge, A., Cockin, A., Webb, K., Frampton, H., Collins, I., Moulds, T., \& Salino, P. (2014). Recovery rates, enhanced oil recovery and technological limits. Phil. Trans. R. Soc. A, 372, 20120320.

10. Otomo, H., Fan, H., Hazlett, R., Li, Y., Staroselsky, I., Zhang, R., \& Chen, H. (2015). Simulation of residual oil displacement in a sinusoidal channel with the lattice Boltzmann method. Comptes Rendus Mécanique, 343(10-11), 559-570.

11. Otomo, H., Fan, H., Li, Y., Dressler, M., Staroselsky, I., Zhang, R., \& Chen, H. (2016). Studies of accurate multi-component lattice Boltzmann models on benchmark cases required for engineering applications. Journal of Computational Science, 17, 334-339.

12. Otomo, H., Crouse, B., Dressler, M., Freed, D. M., Staroselsky, I., Zhang, R., \& Chen, H. (2018). Multi-component lattice Boltzmann models for accurate simulation of flows with wide viscosity variation. Computers \& Fluids.
13. Pinto, M. S., Herrera, D. M., \& Angarita, J. C. G. (2018). Production optimization for a conceptual model through combined use of polymer flooding and intelligent well technology under uncertainties. Revista Fuentes, 16(1), 37-45.

14. Sandiford, B. B. (1964). Laboratory and field studies of water floods using polymer solutions to increase oil recoveries. Journal of Petroleum Technology, 16(08), 917-922.

15. Shan, X., \& Chen, H. (1993). Lattice Boltzmann model for simulating flows with multiple phases and components. Physical Review E, 47(3), 1815.

16. Shan, X., Yuan, X. F., \& Chen, H. (2006). Kinetic theory representation of hydrodynamics: a way beyond the Navier-Stokes equation. Journal of Fluid Mechanics, 550, 413-441.

17. Velandia, J. L. P. (2013). Simulación numérica del flujo bifásico agua-petróleo en un medio poroso. Fuentes: El reventón energético, 11(2), 10.

18. Wassmuth, F. R., Green, K., Hodgins, L., \& Turta, A. T. (2007, January). Polymer flood technology for heavy oil recovery. In Canadian international petroleum conference. Petroleum Society of Canada.

19. Xu, R., Crouse, B., Freed, D. M., Fager A., Jerauld G. R., Lane, N., Sheng Q. (2018). Continuous vs Discontinuous Capillary Desaturation and Implications for IOR/EOR. In Paper SCA2018-066 presented at at the International Symposium of the Society of Core Analysts held in Trondheim, Norway.

20. Yuming, W., Yanming, P., Zhenbo, S., Peihui, H., Rong, L., Ruibo, C., \& Xianhua, H. (2013). The polymer flooding technique applied at high water cut stage in daqing oilfield. In North Africa Technical Conference and Exhibition. Society of Petroleum Engineers.

21. Zhang, R., Shan, X., \& Chen, H. (2006). Efficient kinetic method for fluid simulation beyond the Navier-Stokes equation. Physical Review E, 74(4), 046703. 